\title{
CSR Reporting in Europe
}

\section{M.A. Camilleri, University of Malta, Malta.}

For further information please contact Dr Mark Anthony Camilleri, Resident Academic of Marketing, Department of Corporate Communications, Faculty of Media and Knowledge Sciences, University of Malta, Malta. Email: mark.a.camilleri@um.edu.mt

Keywords: Corporate Social Responsibility, Corporate Sustainability and Responsibility, Global Reporting Initiative, Global Compact, European Union CSR Policy, ESG, Sustainability Reporting, CSR Reporting.

\section{Abstract}

This chapter sheds light on the European Union's (EU) latest strategies, guidelines and principles for Corporate Social Responsibility (CSR), corporate governance and sustainability reporting. It reports on several EU governments' regulatory roles as their societal governance is based on interdependent relationships with stakeholders. As a matter of fact, there are some of the EU countries who have already introduced intelligent substantive and reflexive regulations for their environmental, social and governance (ESG) reporting. Of course, there are different actors and drivers who are shaping CSR communications and policies in relational frameworks with the civil society and corporate businesses. This chapter reports on national CSR policies that are related to the disclosures of non-financial performance of organisations. It transpires that very often, governments, NGOs and corporate businesses resort to non-governmental organisations' regulatory instruments such as process and performance-oriented tools that help them to structure their ESG reports. These instruments usually focus on issues such as labour standards, human rights, health and safety, environmental protection, corporate governance and the like. Therefore, this contribution makes reference to some of the most relevant EU recommendations for the disclosure of integrated reporting. It posits that the way forward is to have more proactive EU governments that raise the profile of CSR. This chapter indicates that any compulsory reinforcement of the regulatory measures may possibly result in efficiencies and operational cost savings for businesses, in the long term. In this light, more effective communication and dialogue between stakeholder groups will help to raise awareness of the public policy case as well as the business case for CSR. Notwithstanding, it is in the businesses' self-interest to anticipate regulatory pressures for ESG initiatives. Ultimately, when businesses implement corporate sustainability and responsibility they forge fruitful relationships with key stakeholders, including the regulatory ones. In doing so, they will also address societal, environmental, governance and economic deficits. 


\section{Introduction}

Corporate Social Responsibility (CSR) has become a well-established concept "whereby companies integrate social and environmental concerns in their business operations and in their interaction with stakeholders on a voluntary basis" (EU, 2002). CSR is now being adopted by more companies, investors and business schools. At the same time, the civil society, academia and media are also becoming very familiar with the CSR agenda. Corporate social responsibility (CSR) necessitates legal compliance as well as 'customary ethics' (Carroll, 1991). In this context, it may appear that a motivation for CSR may be borne out as a necessity to offset the threat of regulation. Evidently, many companies prefer to be one step ahead of government legislation or intervention in order to anticipate social pressures. Arguably, there is always scope for business and government to become more aligned with regards to the regulatory aspect of CSR. Governments can take an active leading role in triggering CSR behaviour among its stakeholders. The businesses themselves will realise that appropriate CSR regulation can possibly bring in economic value as well (Porter and Kramer, 2011). This is also consonant with the European Union's (EU) Lisbon Strategy (2000) and the Gothenburg Sustainability Strategy (2001). According to the European Council's Lisbon Summit; "CSR can make a contribution towards achieving the strategic goal of becoming, the most competitive and dynamic knowledge-based economy (referring to the EU) in the world, capable of sustainable economic growth with more and better jobs and greater social cohesion" (Eurofound, 2003). In 2001, the Gothenburg Sustainability Strategy became the latest strategic goal for the European Union, which supplemented the Lisbon Strategy. The environmental

protection has been given its due importance and was added to the previous two pillars of economic growth and social cohesion (EU, 2014a). On that occasion there was mention of other trends; including climate change, public health, natural resources, sustainable transport, aging population and social exclusion have also been recognised and addressed. However, as it was the case for the Lisbon Strategy, there were significant implementation failures. In order to respond to these deficits, the EU Commission had proposed to reaffirm the 'new approach to policy making and policy coherence' to strengthen its ownership and to improve co-operation with public and private actors, at all levels. EU (2011) had reiterated the importance of CSR as it put forward a new definition for this notion. The term CSR has now been described as the enterprises' responsibility 
for their impacts on society. The EU recommended that the norms of CSR ought to be considered as appropriate model bases for applicable legislation and for collective agreements between social partners. The Organisation for Economic Cooperation and Development (OECD) Guidelines, the United Nations Global Compact (UNGC) and the International Labour Organisation (ILO) Declaration have also received prominent recognition by the governments of the eight largest economies (G8) countries and other states. Their instruments or initiatives are often referenced in academia, or used by business practitioners (Rasche, 2009). Therefore, this chapter sheds light on the latest government-initiated policies on CSR in a European context. It reiterates some of the EU member states' priorities for CSR, whilst making specific reference to recent publications on CSR public policies. It focuses on CSR, sustainability reporting and disclosure.

\section{The CSR Language}

Although the subject of CSR is quite contemporary, it may still be considered as an inherently complex concept by some commentators. It may appear that this dynamic and holistic notion conveys a wide variety of meanings in different contexts. CSR has evolved to meet changing demands in complex environments. Notwithstanding, this concept is context-dependent as it is often embedded in different historical and cultural traditions. This is particularly evident in Europe, where institutions had long been renowned for their "implicit CSR" much before the concept of CSR was even discussed in an explicit manner. Moreover, CSR often embraces and connects to the triple bottom line issues; the economy, society and the environment. Nowadays, CSR is actively pursued and applied by business practitioners, society and government. It transpires that European governments are increasingly using CSR as a vehicle for their public policy goals. Despite its complex nature, the Anglo nations and some other European countries were among the first in the world to adopt public policies that promoted CSR among their businesses. In 2006 and 2007 the EU Commission had taken stock of these policies and published two editions of the "Corporate Social Responsibility: National public policies in the European Union". These compendiums had provided rich information on the member states' approaches to CSR. Lately, EU policy has put forward an action agenda for the period 2011-2014 which covered the following eight areas: 
- "Enhancing the visibility of CSR and disseminating good practices: this includes the creation of a European award, and the establishment of sector-based platforms for enterprises and stakeholders to make commitments and jointly monitor progress.

- Improving and tracking levels of trust in business: the Commission will launch a public debate on the role and potential of enterprises, and organise surveys on citizen trust in business.

- Improving self- and co-regulation processes: the Commission proposes to develop a short protocol to guide the development of future self- and co-regulation initiatives.

- Enhancing market reward for CSR: this means leveraging EU policies in the fields of consumption, investment and public procurement in order to promote market reward for responsible business conduct.

- Improving company disclosure of social and environmental information: the new policy confirms the Commission's intention to bring forward a new legislative proposal on this issue.

- Further integrating CSR into education, training and research: the Commission will provide further support for education and training in the field of CSR, and explore opportunities for funding more research.

- Emphasising the importance of national and sub-national CSR policies: the Commission invites EU member states to present or update their own plans for the promotion of CSR by mid-2012.

- Better aligning European and global approaches to CSR:

○ the Commission highlights the OECD Guidelines for Multinational Enterprises,

○ the 10 principles of the UN Global Compact,

○ the UN Guiding Principles on Business and Human Rights,

○ the ILO Tri-partite Declaration of Principles on Multinational Enterprises and Social Policy,

○ the ISO 26000 Guidance Standard on Social Responsibility”.

(Source: EU, 2011) 


\section{CSR made in Europe}

CSR offers a voluntary complement to traditional hard regulation by persuading private businesses to tackle both domestic and global issues. This way CSR supports public goals as it helps to close governance gaps. Notwithstanding, there are economic and financial measures which can facilitate CSR engagement by stakeholders. For instance, the use of financial incentives and market forces may include tax rebates and abatements, subsidies and awards. Informational instruments pertain to raising awareness through dissemination of knowledge during campaigns, conferences, seminars, training courses and websites. Of course, there is always scope in enhancing the existing relationships between governments and stakeholders. Businesses are urged by governments to reduce their potentially negative impact of their operations on society and the environment (Kotler, 2011). For this reason, there are instances where CSR practices ought to be mandated through legislative and binding regulations. Therefore, the public policy case for CSR can pay off for governments just as the business case can benefit companies. Consequently, this contribution maintains that ever more EU member states should forge relationships with stakeholders to enhance their socially-responsible and sustainable behaviours (Camilleri, 2015).

National settings define frameworks. Public and private actors are directly involved in creating policies and building stakeholder relationships for laudable behaviours. Stakeholder engagement is considered as an important element for solving difficult social and environmental problems (Camilleri, 2015). Encouraging partnerships with key stakeholders has become a central component for European public policy. As a matter of fact in the Danish context, cross-sector local partnerships incorporate the CSR concept (DCCA, 2010; Nidasio, 2004). Companies should be accountable for their social and environmental practices. They are expected to be fair and transparent in their corporate sustainability disclosures (Camilleri, 2012). Generally, the stakeholders are increasingly placing more emphasis on socially-responsible production. For instance, European consumers are increasingly becoming acquainted with organic certifications and 'Fair Trade' initiatives that can possibly improve the identification of products with unique characteristics. Another differential factor that has become quite noticeable in Europe is when government authorities and their public officials lead by example. CSR public 
policies are often viewed as part of the regular framework for social and employment practices. Therefore, a considerable commitment is made by local governments who act as drivers for stakeholder engagement. This will in turn bring social responsibility and environmental sustainability. One way to establish a CSR-supporting policy framework is to adopt relevant strategies and actions in this regard. Strategies define the governments' generic approach to CSR, set specific objectives, priorities for actions which lead to the coordination of a set of existing and new policy instruments. When the objectives are properly implemented, they can be the first step towards CSR policy. Such frameworks may be relevant for those countries that may not have a long CSR tradition or whose institutions lack accountability and transparency credentials (Zadek, Evans \& Pruzan, 2013). Relevant CSR policies have recently been adopted across many member states as explained very well in; "The National Public Policies in the European Union” by Knopf, J., Kahlenborn, W., Hajduk, T., Weiss, D., Feil, M., Fiedler, R. and Klein, J. (2010).

"Belgium's federal CSR action plan was adopted in December 2006, with its first implementation period spanning from 2007 to 2008. The CSR / Socially Responsible Investment (SRI) working group compiled a progress report on the implementation, which was published in March 2009. A stakeholder consultation was organised in November 2008 in order to discuss the current situation regarding the implementation of the measures from the CSR action plan. Eighty-eight organisations took part in the stakeholder consultation, with enterprises being very strongly represented. The aim of this consultation was to provide feedback on the interim results of the implementation and to ask stakeholders how they saw the further implementation of CSR at federal level. Based on this consultation, the CSR/SRI working group wrote a memorandum including several proposals with respect to the future implementation of the action plan.

The Bulgarian strategy uses reporting to monitor progress on its three action plans. For each action plan the Ministry of Labour and Social Policy was required to draft a report on the work carried out by all stakeholders involved. The reports were first submitted to an advisory board and to the council of ministers for approval. In addition, a preliminary assessment of the strategy's implementation must be undertaken at the end of 2010 and a final one in May 2013.

In France, since 2008 a working group including all the different categories of stakeholders involved in CSR ("Comite de suivi du Grenelle de l'Environnement") has been in charge of the follow-up of the implementation of the governmental commitments. Review measures may also be used to improve the management of international instruments. 
In December 2009 the Dutch NCP of the OECD Guidelines submitted itself to a voluntary peer review by NCP colleagues from Canada, Chile, France, Japan and the UK. The review team's report was published in March 2010. To stimulate peer learning by European OECD NCPs, the results of the peer review of the Dutch NCP have been made publicly available on an English version of the website of the Dutch NCP” (adapted from Knopf et al., 2010).

Recently, the Danish government had published its "Action Plan for Corporate Social Responsibility". The aim of this action plan was twofold: to promote CSR among Danish businesses, and to promote sustainable growth both domestically and internationally (Danish National Action Plan, 2014). The action plan comprised 30 initiatives in four key areas: propagating business-driven social responsibility, promoting businesses' social responsibility through government activities, the corporate sector's climate responsibility, and marketing Denmark for responsible growth. With its action plan Denmark was among the forerunners in issuing a CSR strategy (Danish National Action Plan, 2014). The central strategic document has helped to focus and re-emphasise existing instruments and to formulate clear priorities. The Danish action plan was characterised by three strengths. Firstly, it has presented a smart mix of CSR instruments, ranging from informational web tools like the CSR Compass or partnering instruments like the Council on Corporate Social Responsibility to legal instruments such as the much debated legislation on reporting (CSR Compass, 2014). Secondly, it described CSR as a means for improving competitiveness. Therefore this action plan also stressed about the business case for CSR (Camilleri, 2014). Thirdly, Denmark is a very strong supporter of international CSR initiatives, as it was particularly evident from its support to the UN Global Compact and the UN Principles for Responsible Investment (UNPRI) as laid down in its action plan. In fact, Denmark prepared its first biennial progress report in 2010. The government of Denmark reported on the businesses' compliance with its national initiatives. Van Wensen, K., Broer, W., Klein, J. and Knopf, J., (2011) reported that both the Danish and Swedish governments have contributed to a stronger uptake of sustainability reporting. At the same time, many companies in these Scandinavian countries had already started reporting about their corporate social and environmental responsibility, much before they were coerced to do so. 


\section{Sustainability Reporting and Disclosures}

Organisations are increasingly using a wide variety of instruments, tools and channels to communicate their environmental, social and governance (ESG) reports to stakeholders. There are around 2,000 non-financial reports in Europe (EU, 2009). Different organisations across different industry sectors are increasingly valuing sustainability reporting (Camilleri, 2015). Some of the most prevalent reporting schemes were drawn from; the G3 Guidelines of the Global Reporting Initiative (GRI) and the United Nations Global Compact (UNGC). In addition, several platforms and organisations that promote corporate sustainability reporting have developed partnerships with AccountAbility, OECD, UNEP, Carbon Disclosure Project and with many governments and sector organisations (Van Wensen et al., 2011; Kolk, Levy \& Pinkse, 2008). When one explores the key topics that companies report on, it transpires that the disclosure of carbon emissions have become quite a common practice (Kolk et al., 2008) while there is an increased awareness on the subject of human rights and the conditions of employment (Lund-Thomsen \& Lindgreen, 2013). Online reporting has offered an opportunity for accountability and transparency as information is easily disseminated to different stakeholders (Zadek et al., 2013). This has led to an increased stakeholder engagement, integrated reporting and enhanced external verification systems. It may appear that most stakeholders consider reporting schemes as a valuable tool that can improve the quality of their reporting, particularly when it can enable them to benchmark themselves with other companies. GRI is often regarded as 'a good starting point' for this purpose. Moreover, the provision of a UNGC communication on progress is a new global trend that has become quite popular among business and non-profit organisations. Some of the European organisations are gradually disclosing environmental information or certain other key performance indicators that are of a non-financial nature in their reporting (Zadek et al., 2013). The number of companies reporting relevant and material information on their ESG performance has grown significantly in recent years. For instance, the annual global reporting output in 2010 has increased from almost zero in 1992 to an expected output of 4,000 on a worldwide level (Mullerat, 2013). Despite the financial crisis and the subsequent recession, the growth rate of ESG reporting had slowed only marginally during 2009 (Bansal, Jiang, \& Jung, 2014; Knopf et al., 2010). 
Notwithstanding, these reporting companies still constitute a small share of global business and many more small and medium-sized enterprises (SMEs) (Mullerat, 2013; EU 2012).

According to the European Modernisation Directive (2005), companies are required to analyse their non-financial key performance indicators that may be relevant for their particular business (Van Wensen et al., 2011). The European companies are expected to include information relating to their environmental performance as well as on employee matters (Mullerat, 2013). As a matter of fact, it transpires that all EU countries have already implemented these requirements. Some EU states have clearly distinguished between several subtypes of ESG reporting, such as 'Environment in general', 'Environment \& Health \& Safety', 'Environment \& Social', 'Environment \& Health \& Safety \& Community', 'Corporate Social Responsibility', 'Sustainability', 'Integrated', 'Social and Community', and 'Other' (Van Wensen et al., 2011). Interestingly, there were many EU countries that have developed some form of mandatory requirements for ESG disclosures (Ioannou \& Serafeim, 2014). For instance, France was a pioneer in this regard when it enacted the "New Regulations" in 2001 (BSR, 2012; Whiteside, Boy \& Bourg, 2010). Similarly in Denmark, the 1,100 biggest companies as well as state-owned companies, institutional investors, mutual funds and listed financial businesses are expected to provide information about their CSR policies on a "comply or explain" basis in their annual financial reports (DCCA, 2010). Likewise in Sweden, all state-owned companies have to publish their sustainability report (Ioannou \& Serafeim, 2014). The management boards of stock-listed companies and the largest state-owned companies in the Netherlands are also required to report and be accountable to the supervisory board and their stakeholders on CSR issues (Ioannou \& Serafeim, 2014; DCGC, 2014). Evidently, other countries have followed suit as they developed their own voluntary standards or guidelines in order to support companies or other organisations. The latter countries often provide guidance on the integration of social and environmental issues in financial reporting or support certain rankings or awards that are related to sustainability reporting. Generally, it seems that there is a trend towards more government-driven initiatives that are related to reporting. This trend has also been exposed in a recent study that was carried out by KPMG in collaboration with Global Reporting Initiative (GRI), 
United Nations Environment Programme and the University of Stellenbosch Business School. KPMG (2010) reported that standards, codes and guidelines as well as legislation for reporting have increased in the recent years. It has indicated how more reporting companies and organisations were following the guidance of international organisations such as the GRI. Moreover, many governments have recommended new regulations or provided guidance and incentives in order to entice organisations to disclose material information on their ESG performance.

Recently, the European Commission hosted a number of multi-stakeholder seminars and workshops that discussed about the participants' views on ESG disclosure (EU, 2014b). It also put forward reasonable proposals to enhance extant European policies that are related to non-financial reporting. Different stakeholder groups consisted of enterprises, investors, civil society, consumers and media, trade unions and public authorities. An EU Commission Expert Group suggested that their framework on integrated reporting has given a degree of flexibility to the companies to decide on the topics to report on and on the metrics they use (Camilleri, 2015). The EU's (Directorate General of the Internal Market and Services) experts came up with an innovative approach, which incentivised the companies to report their non-financial information. Of course, materiality was considered as a key concern by several audit experts. The experts stressed that improving materiality of reports is useful to address the comparability issues. They advocated that the companies' boards should have ownership on reporting in order to make it relevant and effective. Clearly, the experts did recognise that there were significant differences in national cultural contexts as well as in their respective reporting mechanisms. Some experts have indicated their concern about the consequences of adopting more detailed reporting requirements (including specific KPIs) into EU legislation. On the other hand, they did not reject the idea of proposing a list of topics which could be covered by any company when reporting its responsible practices.

Yet, despite the existence of a European Modernisation Directive (2005), the current EU framework still does not provide a specific reference framework as to the expected quality of the disclosure of the non-financial reports. Moreover, it transpires that there are significant differences in mentalities across different member states, and within particular 
economic sectors (EU, 2011). To date there is still no 'one-size-fits-all' with regards to ESG reporting. For the time being, the instruments for sustainable reporting are not compulsory, although quite a lot of CSR tools and standards have already been developed. Arguably, such initiatives may have directed enterprises to appropriate CSR behaviour by providing good guidance for best-practice through workshops, formal policy guidelines and media releases (EU, 2011). Nonetheless, the European perception is also drawn from a myriad of environmental management tools that measure sustainability performance.

\section{The EU's Regulatory Instruments for Sustainability Reporting}

The EU has recently revised a number of tools and instruments for the reporting of nonfinancial information. The EU Eco-Management and Audit Scheme was initially established in 1995 and was re-examined in 2009 in accordance with Regulation EC No. 1221/2009. EMAS is a reporting tool for companies and other organisations. It necessitates continuous improvements in their environment performance. One of the aims of the latest revision (which came into force in January 2010) was to strengthen the rules on reporting through core performance indicators. Hence, environmental statements needed to become more relevant and comparable, as organisations are reporting their environmental performance on the basis of generic and sector-specific performance indicators.

Furthermore, there are other EU mandatory instruments including the Modernisation Directive, the European Pollutant Release and Transfer Register (E-PRTR), the EU Emission Trading Scheme and the Integrated Pollution Prevention and Control Directive. The EU Accounts Modernisation Directive 2003/51 had amended the Accounting Directives. It stipulated that as from the year 2005 onwards, European companies should include both financial and, where appropriate non-financial key performance indicators that are relevant to the particular business, including relevant information relating to environmental and employee matters (Mullerat, 2013; Van Wensen et al., 2011). However, this directive also maintained that SMEs could be exempted from the nonfinancial reporting obligations in their annual statements (EU, 2012). Another 
amendment of the Accounting Directives (Directive 2006/46) had introduced an obligation for listed companies to include a corporate governance statement within their annual reports (FRC, 2012). By November 2009 all member states had "transposed" the Modernisation Directive and Directive 2006/46 within their national laws (Habek and Wolniak, 2013). Nevertheless, the Modernisation Directive itself did not stipulate any specific requirements in relation to the type of indicators that could be included in annual reports. However, individual EU governments have already undertaken relevant initiatives to provide companies with further guidance to comply with the statutory requirements. Moreover, the European Pollutant Release and Transfer Register (E-PRTR) Regulation 166/2006/EC came into force in February 2006 (EU, 2014c). The E-PRTR Regulation requires operators of facilities to report on emissions and specific substances. The E-PRTR is serving as a Europe-wide register of industrial and non-industrial emissions into air, water, and land, and off-site transfers of waste water and waste. It also includes pertinent information from specific and diffuse sources.

The EU member states responded differently to the European policies and directives. For instance, in the UK the driving forces behind corporate reporting practices were triggered by the financial communities, business players and NGOs (DECC. 2014; Van Wensen et al., 2011). Moreover, the Accounting Standards Board (ASB) had published a reporting statement which also offered best-practice guidance on preparing an Operating and Financial Review. ASB's (2006) statement has provided voluntary guidance that has supported companies to comply with the statutory Business Review requirements. Subsequently, Italy had published a Directors' report on financial statements in 2009 (KPMG, 2010). This report was issued by the Italian Accounting Association. This publication can be considered as good guidance for the implementation of the Modernisation Directive (KPMG, 2010). The document set out in detail what must be included in the annual report to comply with the legislative decree that transposed the Modernisation Directive into Italian law. Additionally, the Public Function Department of the Prime Minister's Office in Italy had published a set of principles for social reporting by the public administration in 2006. While the Italian national agency for the non-profit sector issued some guidelines for the reporting by not-for-profit organisations in 2009. These guidelines had mirrored the GRI's sustainable reporting guidelines 
(KPMG, 2010). The Dutch Accounting Standards Board has also published guidelines for the integration of social and environmental activities in financial reporting. Existing guidelines on annual reporting had been reviewed, and guidance on separate social reporting had also been issued (Van Wensen et al., 2011). These guidelines (that were updated at the end of 2009) covered different specific topics such as reporting on responsible supply-chain practices or assurance. Similarly, the French Observatory for CSR had developed a web-based platform for CSR reporting on behalf of the government. This platform was based on the reflections of a multi-stakeholder committee within the Grenelle environmental framework (Knopf et al., 2010). It covered the most important reporting initiatives and has served as a framework for CSR. The content of this website is constantly checked and updated by an expert committee consisting of different stakeholders who are interested in CSR reporting, in the French context (Whiteside et al., 2010).

Another frequently used approach that raises awareness of CSR reporting is the organisation of events, including conferences and seminars. These fruitful events often provide capacity building opportunities as well as useful information to companies. For instance, the Polish Ministry of Economy and CSRinfo frequently organise conferences that are related to CSR (Knopf et al., 2010). Some of recent conferences on CSR reporting have mainly addressed medium-sized and large companies. During these fora different stakeholders discuss trends as well as practical aspects of reporting, verification systems and communication of CSR among other issues. Seventeen countries have exercised the option of exempting small entities from having to disclose material information on their non-financial performance (Van Wensen et al., 2011). The UK Companies Act 2006 is an example of the successful implementation of the Modernisation Directive (Clark \& Knight, 2008). All UK companies other than small ones have been mandated to provide information in their annual reports on their strategies, performance and risks (the so-called Business Review). Moreover, quoted companies (as defined in section 385 of the UK Companies Act) ought to disclose information on; environmental, workplace, social and community matters in their annual reviews. They are also expected to report relevant information about their companies' policies in relation to these matters and about their effectiveness. Recently, there were 
developments in specific thematic areas that were taking place in the UK context. The Climate Change Act was enacted in the UK in 2008 (CCA, 2008). Government legislation on corporate reporting had mandated companies to measure and report their emissions. The British government has also reviewed how the reporting on greenhouse gas emissions was successful in addressing the previously set climate change objectives. The UK government had committed itself to carbon reduction as it introduced certain regulations that required disclosures by companies (Kolk et al., 2008). Moreover, an Energy Efficiency Scheme (CRC) required some companies to measure all their emissions which were related to energy use (DECC, 2014). These businesses were required to report their emissions to the Environment Agency. Therefore, British organisations were obliged to comply with the CRC and had to submit a Footprint Report of their total energy and emissions together with their annual reports.

In addition to the Modernisation Directive, a number of European countries have adopted certain laws and regulations that went beyond their requirements (refer to Figure 1). Most of the EU member states have used a "comply or explain" approach rather than giving the option of not reporting.

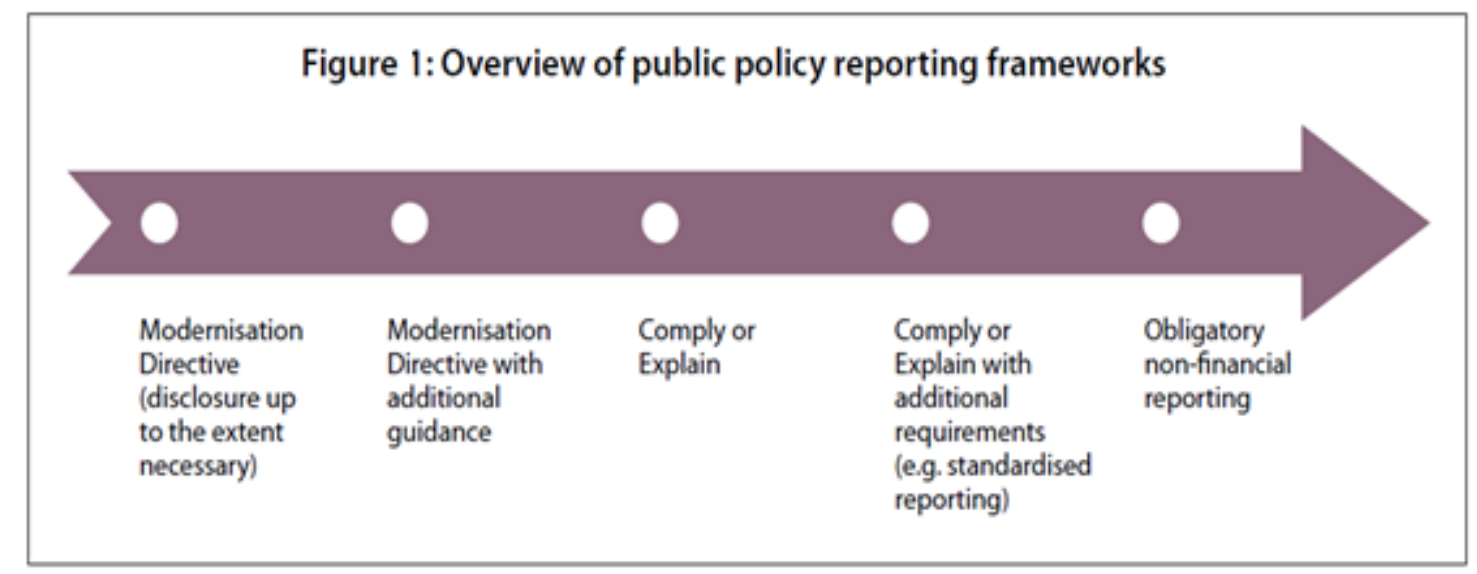

(Adapted from Knopf et al., 2010)

In the Netherlands, CSR reporting had become mandatory in 2008 (Ioannou \& Serafeim, 2014). The Dutch stock-listed companies were expected to report their non-financial performance on the basis of "comply or explain" (Knopf et al., 2010). All stockexchange-listed companies registered in the Netherlands and with a balance sheet of more 
than $€ 500$ million were mandated to do so. These provisions were integrated into the Dutch code for corporate governance, which has been legally anchored in the Dutch Civil Code (DCGC, 2014). These obligations required companies to explain how they were implementing international best practice for their management and supervisory boards. An independent Monitoring Committee for Corporate Governance was also set up to ensure that the businesses complied with the specific provisions of this code (DCGC, 2014). The Monitoring Committee also published regular reports on compliance in English.

In a similar vein, Denmark has also mandated its 1,100 biggest companies as well as its state-owned companies from 2009 onwards to report on their non-financial performance. Companies were required to provide information on their policies for CSR or sustainable and responsible investment (DCCA, 2010). Their comprehensive reports were also expected to elaborate how CSR policies were implemented. Organisations should also have explained their results, and clarified on the management expectations for the future. Denmark did not develop its own standard as it encouraged the use of international reporting frameworks (such as the UN Global Compact and the related Communication on Progress or GRI and the Guidelines for Multinational Enterprises of the Organisation for Economic Co-operation and Development). Although CSR and SRI initiatives are still voluntary in nature; the businesses without relevant policies on responsible behaviours are obliged to justify themselves in this respect. No specific format has been prescribed for providing this additional information in the companies' annual statements or on the corporate websites. However, the annual financial reports should clarify where the nonfinancial information is readily available for stakeholders. In Denmark the legislation on corporate reporting has been an important trigger for active engagement (Danish National Action Plan, 2014).

In France, Article 53 of the first Grenelle law of 3 August 2009 had set the target of extending the New Economic Regulation (NER) Act to large, listed enterprises (Whiteside et al., 2010). The regulation had extended the reporting obligation to majorityowned public companies. Some of the government's parastatal organisations had harmonised the sectoral indicators at the community level. Generally, they agreed with 
the principle of the recognition of the responsibility of parent companies over their subsidiary companies - in the event of serious environmental damage. Interestingly, France had also proposed a working framework (at the EU level) for the establishment of social and environmental standards that allowed companies to benchmark their nonfinancial performance with other organisations (Whiteside et al., 2010).

The Swedish state-owned companies were required to publish their sustainability report since January 2008. The sustainability reports that complied with the GRI guidelines had to be quality-assured by independent checks. It transpired that 55 state-owned companies had published their sustainability reports based on the "comply or explain" principle (Van Wensen et al., 2011). The state owned companies' financial reports had to explain how the GRI guidelines were being applied as they were also expected to justify themselves on any significant deviations. ESG reporting of state-owned companies has increased dramatically. As a matter of fact, more than 94 per cent of these companies had issued their GRI reports. Sweden is now the second country in Europe with the highest number of GRI reports. A recent study by Uppsala University (commissioned by the Swedish Ministry of Enterprise) that has investigated the actual effects of the government's reporting requirements on the state-owned companies' sustainability performance revealed that the introduction of the new guidelines have affected the companies to varying degrees (Knopf et al., 2010). It transpired that the companies that lacked previous experience in sustainability reporting have gone through a more extensive process of change than those that were already submitting sustainability reports. The study has indicated that the reporting requirements have led to increased commitment and awareness, more structured work and more structured processes. Moreover, it was more evident that the sustainability issues have moved up the agenda of organisations as they were given higher priority by managements and boards.

Spain and Portugal opted for additional legislation that was primarily directed at stateowned companies. Reporting by state-owned companies was mandated in Spain's Sustainable Economy Law, which was approved by the cabinet in March 2010 (Kessler and Cuerpo, 2011). This law also included various other disclosure requirements such as the remuneration of company directors. It is now compulsory for the Spanish state-owned 
companies to publish sustainability reports in accordance with commonly accepted standards. In Portugal the Ministers' Council had adopted a resolution on the principles of good corporate governance of state companies. The Minister of Finance has been entrusted with its annual assessment and its implementation (Kessler and Cuerpo, 2011).

Other related examples of legal initiatives also included mandatory reporting in specific areas of sustainability performance. For instance, Ireland's Credit Institutions Act (2008) stipulated that financial services companies have to issue a CSR report of their activities through the Irish Banking Federation. Similarly, in 2006 the Portuguese Department of Transportation and Communications had mandated the companies that are under its guardianship to publish a sustainability report (KPMG, 2010). Moreover, the Cypriot Corporate Governance Code (2002) specified that listed companies were required to report on their corporate governance issues. In addition, as from 2007 the companies that were listed in the Alternative Market were instructed to report their non-financial performance on a "comply or explain" basis (Knopf et al., 2010).

Few countries are using financial or economic instruments to foster CSR reporting. Spain had created incentives for companies to include or develop CSR policies, including reporting. Article 37 of the Sustainable Economy Law stipulates that; "the government shall provide companies, especially SMEs, with guidance and indicators that provide support for self-assessment in relation to their social responsibility, as well as reporting models or references that are in line with international reporting frameworks" (Knopf et al., 2010). The definitions of CSR indicators as well as their reporting mechanisms were developed in cooperation with the State Council (Kessler and Cuerpo, 2011). Moreover, the Spanish Law suggests that the companies that achieve the defined minimum threshold can qualify as socially responsible companies, if they decide to request recognition. Moreover, the official Spanish Credit Institute has partnered with a Caja Navarra (a regional savings bank) to promote reporting among SMEs. Caja Navarra has even offered its clients simple electronic tools that helped them to produce a standardised CSR report. Curiously, since there was this initiative more than 1,100 SMEs have prepared their first CSR report following the launch of this campaign in 2009 (Knopf et al., 2010). 
The Czech Republic has implemented an award for CSR and quality management. To qualify for the National Prize of Quality, participants may publish a CSR report, and submit it to government (Knopf et al., 2010). This CSR report had to be developed according to a specific framework, which is readily available (and free) for download. All the reports are assessed by independent evaluators, who will adjudicate the best report and have it published. In Finland the Ministry of Employment and the Economy, the Ministry of the Environment and different businesses organise annual competitions on ESG reporting (KPMG, 2010). Since 2008, these competitions have been broadened in scope. Now, they also include the term CSR in addition to environmental reporting. The German Ministry of Labour and Social Affairs in collaboration with the German Council for Sustainable Development, has also participated in a project that ranked the sustainability reports of industrial and service companies in Germany (Transparency International, 2012). Since 2009, there has also been a classification of the best sustainability reports that were prepared by SMEs (Knopf et al., 2010). Some of the underlying objectives of such competitions are: to benchmark best practices in sustainability reporting; to improve constructive competition between companies and to foster dialogue between different stakeholder groups. The ranking of the best sustainability reports is carried out by independent research organisations.

Other existing instruments include sustainable public procurement policies, whereby the governments as buyers can create a positive climate for sustainability reporting. For instance, a case in point is the Dutch government that had mandated the disclosure of ESG as a requirement for its suppliers in 2010 (Ioannou \& Serafeim, 2014). Another example of a Dutch instrument that combined aspects of both economic and informational instruments is the recently updated Transparency Benchmark. Since 2004 it has been continuously developed and updated by the Ministry of Economic Affairs in the Netherlands. There was continuous dialogue with stakeholders that have translated to lower information costs for both companies and readers of CSR reports. To achieve this outcome, the Ministry had incurred the initial development costs of the transparency benchmarks and limited the participation to less than 100 companies (Knopf et al., 2010). In 2010 this instrument was extended to a total of 500 companies. These included a number of state-owned companies, at the request of the Ministry of Finance. In a similar 
vein, the Danish Commerce and Company Agency had also supported a set of tools that may improve CSR reporting (DCGC, 2014). The different instruments included the CSR Compass that has provided insightful guidance on CSR in the supply chain (CSR Compass, 2014). Interestingly, SMEs were also supported on how to implement the 10 Global Compact Principles. Most of these tools were employed in close partnership with other actors. It transpires that these instruments have provided companies with relevant information on different CSR-related topics and they have given practical support for corporate reporting.

\section{The Way Forward}

A number of upcoming initiatives are either in the planning phase or may still have to be approved by the EU governments. For example, the Spanish State Council on Corporate Social Responsibility has set up a "Working Group on Transparency, Reporting and Standards" (Knopf et al., 2010). It is hoped that this working group will provide a professional guidance to organisations that are / shall be publishing their sustainability reports. Perhaps there is a need to regulate further in the area of ESG reporting. The Italian National Contact Point, the Italian Bankers' Association and the Italian National Business Association have been cooperating to define a set of standards for non-financial reporting. Therefore, the organisations that are reporting a true and fair view of their socially responsible, environmentally sustainable or corporate governance practices may have their credit ratings appraised by Italian banks (Knopf et al., 2010). The German CSR strategy (2008) maintained that the Federal Ministry of Employment and Social Affairs and the Federal Ministry for the Environment, Nature Conservation and Nuclear Safety had to publish CSR reports based on GRI and the EMAS declaration (Progress Report, 2008). These reports were published in the first reporting year following the launch of the strategy. In Belgium the federal government decided to carry out a trial project concerning the application of ISO 26000 in government agencies (Knopf et al., 2010). This initiative was linked to sustainability reporting that was also based on the guidelines of the GRI and was piloted with the Federal Public Planning Services Division for Sustainable Development. Other member states have decided to become more active in ESG disclosure. For instance, Bulgaria had identified the need to regulate the obligation to draw up social reports in its national action plan. Whilst in Poland, CSR will be 
advanced in the form of an inter-ministerial working group (Martinuzzi et al., 2011). Extensive discussions have been taking place on the future of reporting in the Polish context. The working group has recently submitted its recommendations on increasing transparency and reliability which will form the basis for future activities in the area of developing policy measures for ESG disclosure.

Generally, it may appear that EU countries are opting for a mix of voluntary and mandatory measures to improve their ESG disclosure. While all member states have implemented the EU Modernisation Directive, they have done so in different ways. While the Modernisation Directive ensures a minimum level of disclosure, it is in many cases accompanied by intelligent substantive legislation. National governments ought to give guidance or other instruments that support improvements in sustainability reporting. Lately, there is a trend towards the development of regulations that integrate existing international reporting frameworks such as the GRI or the UN Global Compact Communication on Progress. These frameworks require the engagement of relevant stakeholders in order to foster a constructive environment that brings continuous improvements in ESG disclosures.

\section{Conclusion}

Regular stakeholder engagement as well as strategic communications can bring more responsible organisational behaviours (Camilleri, 2015). Many corporate businesses use non-governmental organisations' regulatory tools, processes and performance-oriented standards with a focus on issues such as labour standards, human rights, environmental protection, corporate governance and the like. Nowadays, stakeholders, particularly customers expect greater disclosures, accountability and transparency in corporate reports. This chapter maintained that the way forward is to have more proactive European governments which address societal, environmental, governance and economic deficits. It reported how governments' regulatory roles with stakeholders are intrinsically based on relational frameworks with civil society and commercial entities. Governments have a vital role to play in improving on the environmental and social practices of business and industries operating from their country (Camilleri, 2015). At the moment, we are witnessing regulatory pressures for mandatory changes in CSR reporting (EU, 2014b). 
Yet, there is a need for additional empirical evidence which analyse how the European disclosure regulations may have positively or adversely affected the corporations' shareholders. Perhaps, firms may respond differently to reporting regulations as there are diverse context and realities in Europe. Of course, EU regulatory pressures are responding to energy crises and addressing contentious issues such as resource deficiencies including water shortages. Notwithstanding, firms are also tackling social issues and implementing certain environmental initiatives (e.g. waste reduction, alternative energy generation, energy and water conservation, environmental protection, sustainable transport et cetera). Perhaps, governments may offer fiscal incentives and enforce regulation in certain areas where responsible behaviour is needed (Camilleri, 2015). This chapter has reported how regulatory changes in certain EU countries involved the efficient and timely reporting of sustainable (responsible) practices. It indicated that ESG reporting is primarily aimed at the larger businesses rather than SMEs. Undoubtedly, the governments may act as drivers of CSR policy as they can provide structured compliance procedures. Regulatory authorities are expected to explain their strategic objectives to business stakeholders and NGOs. The CSR practices and their measurement, their reporting and audit should be as clear and understandable as possible for businesses. The governments' reporting standards and guidelines may be drawn from the international reporting instruments (e.g. GRI, Compact, ISO, SA and AA). Nevertheless, it must be recognised that there are different businesses out there which consist of various ownership structures, sizes and clienteles. In addition, there are many stakeholder influences which may possibly affect the firms' level of social and environmental engagement (Camilleri, 2015).

Although regulation is desired to limit the pursuit of exploitative, unfair, or deceptive practices, this contribution has shown that in some cases regulation (and legislation) is taking the form of "comply or explain" mandates. This chapter posited that it is in the businesses' self-interest to anticipate such regulatory intervention, They ought to implement sustainable environmental initiatives and meet corporate governance guidelines to mitigate their effects. It may be argued that any compulsory reinforcement of the regulatory measures may possibly yield operational efficiencies and cost savings for businesses, in the long term. In this light, more communication and dialogue between 
stakeholder groups will help to raise awareness of the public policy and business cases of CSR. Many EU governments are realising that laudable social and environmental behaviours can lead to economic growth, social cohesion and sustainable environmental practices.

\section{References}

ASB (2006). Reporting Statement: Operating and Financial Review. https://www.frc.org.uk/Our-Work/Publications/ASB/Reporting-Statement-Operatingand-Financial-Review-File.pdf Accessed 30th August, 2014.

Bansal, P., Jiang, G. F., \& Jung, J. C. (2014). Managing responsibly in tough economic times: strategic and tactical CSR during the 2008-2009 global recession. Long Range Planning.

BSR (2012). Trends in ESG Integration In Investments https://www.bsr.org/reports/BSR_Trends_in_ESG_Integration.pdf Accessed on the 20th September 2014.

Camilleri, M.A. (2012). A Review of Regulatory Instruments and Guidelines in Social and Environmental Behaviour. Working Paper at Nyenrode Business Universiteit, Netherlands in an EABIS 2012 Colloquium, entitled; Valuing Non-Financial Performance.

Camilleri, M.A. (2014). Advancing the Sustainable Tourism Agenda Through Strategic CSR Perspectives. Tourism Planning \& Development, 11(1), 42-56.

Camilleri, M.A. (2015). Valuing Stakeholder Engagement and Sustainability Reporting. Corporate Reputation Review (18) 2.

Carroll, A.B. (1991). The Pyramid of Corporate Social Responsibility: Toward the Moral Management of Organizational Stakeholders. Business Horizons 34 (4) 39-48. 
CCA (2008). Climate Change Act.

http://www.legislation.gov.uk/ukpga/2008/27/contents Accessed 2nd October, 2014.

Clark, G.L. \& Knight, E.R. (2008). Implications of the UK Companies Act 2006 for institutional investors and the market for corporate social responsibility. Journal of International Law, 11, 259.

CSR Compass (2014). Responsible supply chain management.

http://www.csrcompass.com/responsible-supply-chain-management Accessed 23rd September, 2014.

Danish National Action Plan (2014). Implementation of the UN Guiding Principles on Business and Human Rights. Danish Business Authority, Copenhagen. http://www.ohchr.org/Documents/Issues/Business/NationalPlans/Denmark_NationalPlan BHR.pdf Accessed 30th September 2014.

DCCA (2010). Corporate Social Responsibility and Reporting in Denmark. Danish Commerce and Companies Agency.

http://samfundsansvar.dk/file/319099/corporate_social_responsibility_and_reporting_in_ denmark_september_2010.pdf Accessed 14th September 2014.

DCGC (2014). Dutch Corporate Governance Code: Principles of good corporate governance and best practice provisions.

http://commissiecorporategovernance.nl/download/?id=606 Accessed on the $2^{\text {nd }}$ October, 2014.

DECC (2014). UK National Energy Efficiency Action Plan. Department of Energy and Climate Change. http://ec.europa.eu/energy/efficiency/eed/doc/neep/2014_neeap_unitedkingdom.pdf Accessed 29 ${ }^{\text {th }}$ August, 2014.

EU (2002). Corporate Social Responsibility: A business contribution to Sustainable Development. $\operatorname{COM}(2002) 347$ final. Commission of the European Communities, Brussels. 
EU (2011). A renewed EU strategy 2011-14 for Corporate Social Responsibility. http://ec.europa.eu/enterprise/newsroom/cf/_getdocument.cfm?doc_id=701 Accessed 3rd February 2013.

EU (2012). Sustainable and responsible business European Expert Group on corporate social responsibility (CSR) and SMEs.

http://ec.europa.eu/enterprise/policies/sustainable-business/corporate-socialresponsibility/sme/european-expert-group/index_en.htm Accessed 12th July 2014.

EU (2014a). Sustainable Development. http://ec.europa.eu/environment/eussd/ Accessed 14th June 2014.

EU (2014b). Non-Financial Reporting. http://ec.europa.eu/internal_market/accounting/non-financial_reporting/index_en.htm Accessed 25th June 2014.

EU (2014c). European Pollutant Release and Transfer Register (PRTR). http://europa.eu/legislation_summaries/environment/general_provisions/128149_en.htm Accessed 29th August, 2014.

Eurofound (2003). Towards a sustainable corporate social responsibility. European Foundation for the improvement of Living and Working Conditions. Office for Official Publications of the European Communities, Luxembourg.

FRC (2012). The UK Corporate Governance Code. Financial Reporting Council. https://www.frc.org.uk/Our-Work/Publications/Corporate-Governance/UK-CorporateGovernance-Code-September-2012.aspx Accessed 3rd October, 2014.

Hąbek, P. \& Wolniak, R. (2013). European Union regulatory requirements relating to Sustainability Reporting: The case of Sweden. Scientific Journals Maritime University of Szczecin, Zeszyty Naukowe Akademia Morska w Szczecinie. 
Ioannou, I. \& Serafeim, G. (2014). The consequences of mandatory corporate sustainability reporting. Harvard Business School Research Working Paper 11-100.

Ireland's Credit Institutions Act (2008).

http://www.irishstatutebook.ie/2008/en/act/pub/0018/ Accessed 19 $9^{\text {th }}$ September 2014.

Kessler, A. \& Cuerpo, C. (2011). Macroeconomic Impact of the Sustainable Economy Law. Documentos de Trabajo, 03.

Knopf, J., Kahlenborn, W., Hajduk, T., Weiss, D., Feil, M., Fiedler, R. \& Klein, J. (2010). Corporate Social Responsibility National Public Policies in the European Union. EU Commission, Brussels.

Kolk, A., Levy, D., \& Pinkse, J. (2008). Corporate responses in an emerging climate regime: the institutionalization and commensuration of carbon disclosure. European Accounting Review, 17(4), 719-745.

Kotler, P. (2011). Reinventing marketing to manage the environmental imperative. Journal of Marketing, 75(4), 132-135.

KPMG (2010). Carrots and Sticks - Promoting Transparency and Sustainability. An update on trends in Voluntary and Mandatory Approaches to Sustainability Reporting. KPMG in collaboration with United Nations Environment Programme and Global Reporting Initiative in Africa. https://www.globalreporting.org/resourcelibrary/CarrotsAnd-Sticks-Promoting-Transparency-And-Sustainbability.pdf Accessed 01st October, 2014.

Lund-Thomsen, P. \& Lindgreen, A. (2013). Corporate Social Responsibility in Global Value Chains: Where Are We Now and Where Are We Going?". Journal of Business Ethics, 1-12.

Martinuzzi, A., Krumay, B. \& Pisano, U. (2011). Focus CSR: The New Communication of the EU Commission on CSR and National CSR Strategies and Action Plans. European Sustainable Development Network (ESDN), Quarterly Report No, 23. 
Mullerat, R. (2013). Corporate social responsibility: a European perspective. Jean Monnet/Robert Schuman Paper Series Vol. 13 No. 6, June 2013.

Nidasio, C. (2004). Implementing CSR on a large scale: The role of government. In $3 r d$ Annual Colloquium of the European Academy of Business in Society, Ghent.

Porter, M.E. \& Kramer, M.R. (2011). Creating Shared Value. Harvard Business Review (89) $1-2$.

Progress Report (2008). For a Sustainable Germany. German Strategy for Sustainable Development.

http://www.nachhaltigkeitsrat.de/fileadmin/user_upload/English/strategy/2008/German_ Govt_NSDS_progress_report_08_E.pdf Accessed 10 ${ }^{\text {th }}$ October, 2014.

Rasche, A. (2009). Toward a model to compare and analyze accountability standards the case of the UN Global Compact. Corporate Social Responsibility and Environmental Management 16 (4) 192-205.

Transparency International (2012). GRI: Germany's corporate reports do not deliver what they promise. https://blog.transparency.org/2012/12/11/gri-germanys-corporate-reportsdo-not-deliver-what-they-promise/ Accessed $21^{\text {st }}$ September 2014.

Van Wensen, K., Broer, W., Klein, J. \& Knopf, J. (2011). The State of Play in Sustainability Reporting in the European Union. European Commission, Brussels. http://ec.europa.eu/social/BlobServlet?docId=6727\&langId=en Accessed $7^{\text {th }}$ June 2014.

Whiteside, K. H., Boy, D., \& Bourg, D. (2010). France's 'Grenelle de l'environnement': openings and closures in ecological democracy. Environmental politics, 19(3), 449-467.

Zadek, S., Evans, R., \& Pruzan, P. (Eds.). (2013). Building Corporate Accountability: Emerging Practice in Social and Ethical Accounting and Auditing. Routledge. 
